\title{
GQ8 ARE WE SERIOUS ABOUT ENDING HUNGER?*
}

\section{ABSTRACT}

Efforts to end hunger in the world have not led to significant improvements. There has been some progress but, apparently, global efforts to end hunger have not been serious. They could not have been expected to lead to the achievement of that goal.

Many food policy analysts have shifted their attention to the issue of sustainability, with some focusing on the ways in which agricultural production might be harmed as a result of climate change. The sustainability of the world's food system into the future is important, but it may be drawing attention away from the hunger problem that is already very real for millions of people. The sustainability and hunger issues should be addressed together.

KEY WORDS: Hunger, food security, sustainability, climate change

${ }^{*}$ George Kent, University of Hawaii, Deputy Editor of World Nutrition, is also its Curator of Good Questions. This is the eighth in the Good Questions series. 
Talk about ending hunger in the world has been going on for decades, but it has not led to significant improvements. As indicated in the chart below, currently around 800 million people suffer from hunger (FAO, IFAD, UNICEF, WFP and WHO 2018, 3; also see Chauhan 2019; FAO 2019, 6; Gunawardena 2019; Kripke 2019). Hunger-sometimes described as undernutrition or food insecurity - refers primarily to the deficit in energy (calorie) intake. There are other forms of malnutrition such as specific nutrient deficiencies and obesity (Branca et al. 2019; Global Nutrition Report 2019), but it is widely agreed that the primary indicator of hunger is energy deficiency.

For most of us in the comfortable world, hunger is not very troubling. It affects others, not our people. However, when we are told that climate change threatens the world's food supply, it grabs our attention. We begin to recognize that hunger could become a problem for our people as well.

Many people in high-income countries think of the hunger problem as something that happens far away, mainly in Africa and Asia. But it also happens close to home, as shown repeatedly by the U.S. government's regular survey of food security (USDA 2019). In high income countries, reports about local hunger show up only rarely in the local press (Geraghty 2019).

\section{FIGURE 1}

THE NUMBER OF UNDERNOURISHED PEOPLE IN THE WORLD HAS BEEN ON THE RISE

SINCE 2015, AND IS BACK TO LEVELS SEEN IN 2010-2011

19 1237

17 1107

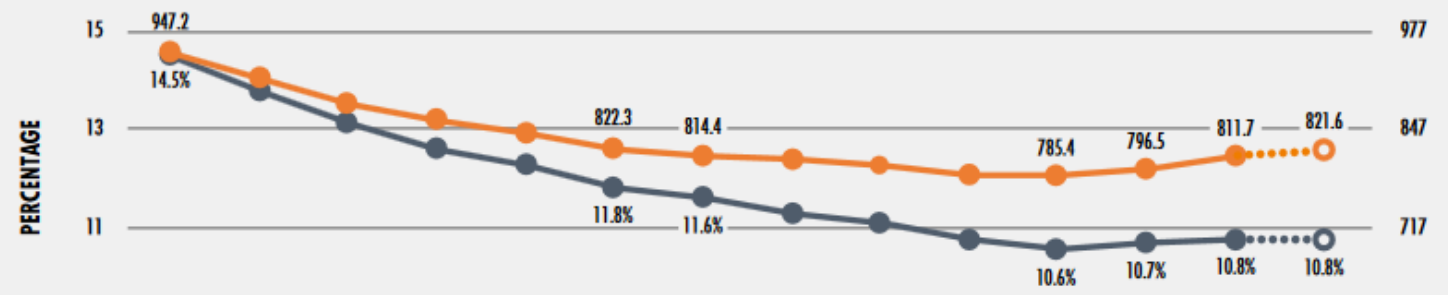

9

5

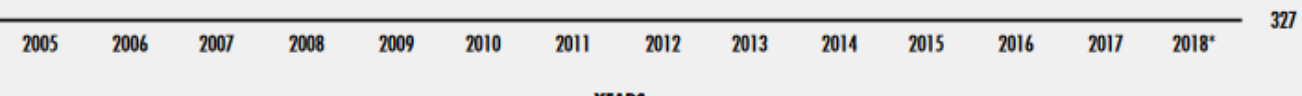
YEARS

$\longrightarrow$ Prevalence of undernourishment (percentage)

$\longrightarrow$ Number of undernourished (millions)

NOTES: * Values for 2018 are projections os illustrated by dofted lines and empty circles. The entire series was carefully revised to reflect new information made available since the publication of the last edition of the report; it replaces all series published previously. See Box 2.

SOURCE: FAO. 
Source: FAO, IFAD, UNICEF, WFP and WHO. 2018. The State of Food Security and Nutrition in the World 2018: Building Climate Resilience for Food Security and Nutrition. Rome: FAO, page 3. http://www.fao.org/3/I9553EN/i9553en.pdf

The number of people who are hungry worldwide has been around 800 million for many years. This is in sharp contrast to the progress on other fronts, such as the rapid reduction in child mortality worldwide (Katz, et al. 2019).

\section{NO SERIOUS PLANS TO END HUNGER}

While here has been some progress in reducing hunger (Roser and Ritchie 2019), global efforts to end hunger have not been serious, in the sense that they could not have been expected to achieve that goal (Kent 1984; 2004; 2011a; 2011b: 167-168).

The problem is well illustrated by the major document on hunger to come out of the Millennium Development Project. Its Strategic Approach for Halving Hunger was based on seven vague recommendations (UN Millennium Project 2005: 59):

- Forging a global partnership

- Promoting good governance

- Mainstreaming gender equality

- Adopting a people-centered approach

- Investing in science and technology

- Vulnerability analysis—a tool for setting priorities

There was no substantial commitment of resources, no management group to control the process, no realistic timeline, and no means for mid-course corrections on the way to the goal. There were no contracts with agencies that would work toward achievement of the goal. It would not be possible to build even a simple bridge across a river without a careful stepwise plan for the building process. Hoping for a bridge or hoping for the end of hunger won't work. Hope is not a strategy.

The UN system offers little more than vague aspirations. In 2018, the UN's General Assembly adopted a resolution calling for action toward "a healthier world through better nutrition (UNGA 2018).” Only the United States and Libya opposed the resolution (Nestle 2019a). The aspirations sounded good, but the document did not commit any country to do anything specific. The reason for the preparation of this document is not clear.

In the same year, the FAO released its Policy Guidance Note 12 to help policymakers address the food security and nutrition situation in their country (FAO 2018). It offered what they called a stepwise approach with a policy focus on "nutrition sensitive" food systems:

Step 1. Conducting a situational analysis

Step 2. Mapping the policy landscape

Step 3. Analysing the policy framework 
Step 4. Bringing about policy change

It was not clear what would be done about countries in which policy makers showed little interest in their food situation. It was not clear what would be done where the private sector is likely to resist changes.

The Millennium Development Goals have been updated in the Sustainable Development Goals. Again, there have been serious obstacles to their achievement, obstacles that could have been foreseen (Deen 2019).

There are similar shortfalls in the work of nongovernmental agencies. The International Food Policy Research Institute says:

IFPRI's vision is a world free of hunger and malnutrition. Its mission is to provide research-based policy solutions that sustainably reduce poverty and end hunger and malnutrition (IFPRI 2019).

It supports a broad variety of projects on food issues. Some seem worthwhile. However, the concern here is not with particular projects, but with how the projects fit together. Is IFPRI actually "Accelerating the End of Hunger \& Malnutrition," as it claims, or is it simply doing some good works here and there? Can IFPRI's voyage be expected to reach the destination? How is the way-finding being managed?

The Hunger Project is another nongovernmental organization that does excellent projects, but they do not match up with its earlier high hopes for helping to bring about the actual end of hunger (The Hunger Project 1985).

There is some accountability with regard to nutrition goals in the annual reports of the United Nations System Standing Committee on Nutrition (UNSCN) to the United Nations Economic and Social Council. They include descriptions of many activities, but few indications of substantial achievement in ending hunger and other forms of malnutrition. The UNSCN Coordinator "underlined the importance of systemic change and food-system transformation to achieving Sustainable Development Goal (SDG) 2 to eradicate hunger, as well as all of the other SDGs," but did not explain how that would happen (UNSCN 2019). The UNSCN website has a permanent headline that says, "A world free from hunger and all forms of malnutrition is attainable in this generation." If it is to be meaningful, this claim should be linked to a specific plan.

The top organization dealing with these issues in the United Nations system is the Committee on World Food Security (CFS 2019). It reports on many different nutrition-related activities, but it does not say much about the prospects or the means for achieving the goal of ending hunger.

Many of the flaws in large-scale global programs for dealing with hunger also appear in national programs. Where the U.S. government sets up nice goals such as "Reduce household food insecurity and in doing so reduce hunger," Marion Nestle points out: "the process does not define 
how these goals are to be accomplished or who is responsible for accomplishing them (Nestle 2019b).” If the goals are not linked to a serious plan, what is the point of stating those goals?

Over the decades, the stated global goal of ending hunger was not achieved, repeatedly. Instead of strengthening the effort, the response has been to reduce the aspirations (Hickel 2016; Kent 2010a; 2016: 102-106; Pogge 2004; Pogge 2016). That is a clear indicator of the lack of seriousness.

\section{THE ROLES OF THE FOOD INDUSTRY}

The EAT-Lancet work was done in close collaboration with the World Business Council for Sustainable Development. It focuses on increasing agricultural production for the growing world population (WBCSD 2019). Apparently, their unquestioned premise is that the benefits of strengthening industrial large-scale agriculture will somehow find their way to those who have trouble obtaining enough good food.

The interests of the food industry were very clear in the WBCSD release to the news media at the economic summit at Davos in 2017, headlined "25 Leading Global Companies Join Together to Accelerate Transformational Change in Global Food (WBCSD 2017).” Their program was "designed to accelerate transformational change in global food systems, to reach healthy, enjoyable diets for all, that are produced responsibly within planetary boundaries.”

The industry focuses on the idea that more food will need to be produced for the growing population. That is not the hunger problem. Hunger was mentioned as a one-line factoid in a box on Background Information, but not discussed. The transformational change envisioned by the business leaders was not one likely to be supported by people concerned about widespread and persistent hunger in the world. Many food companies claim to be fighting world hunger, but none are likely to support bold action if it threatens their returns to investors (Nestle 2019c).

The EAT-Lancet report was followed by a report from the Lancet Commission on Obesity. It focused on the role of powerful commercial interests in food systems, and the need to control them. They called for a new global treaty to limit the influence of Big Food. The Commission voiced concern for hunger as well as for obesity, but did not propose specific goals or a strategy for achieving them (The Lancet 2019a, 2019b, 2019c). As others have done in the past, they listed a variety of helpful actions that could be taken by different agencies (The Lancet 2019a), but did not say what would motivate the agencies to take those actions.

The EAT-Lancet Commission on Food, Planet, Health, says it is "delivering the first full scientific review of what constitutes a healthy diet from a sustainable food system, and which actions can support and speed up food system transformation (EAT 2019; EAT-Lancet 2019).” It examines familiar questions: What is a healthy diet? What is a sustainable food system? What are the trends shaping diets today? Can we achieve healthy diets from sustainable food systems? How? What are the solutions and policies we can apply? Their approach has been severely criticized (Barclay 2019; Pearson 2019; Steele 2019). It focuses on how people with many options could make wiser choices of what to eat. It doesn't address the plight of those who have few options because they have little money. If the food industry is going to help end hunger in 
the world, it must find ways to help poor people provide for themselves. They could make a good start by ensuring that everyone who works in the industry is well paid.

EAT-Lancet's premise appears to be that showing people what selected experts think is the wiser choice for their health or for the environment means they will choose it. That is simply not true. It is especially untrue when the experts themselves are divided, as shown by the criticisms of the EAT-Lancet project.

The Scaling Up Nutrition (SUN) program is another example of a Global Public-Private Partnership GPPP) in which the food industry is integral to the approach, focusing on market and technology-based solutions to nutrition problems and marginalizing right to food advocates (Lie 2019). SUN has been a top-down program, with little space for the voices of civic society:

While GPPPs are promoted as necessary and effective mechanisms to solve development challenges, they reflect a shift in authority away from states in favor of nonstate actors, raising issues about legitimacy. In global health, critics argue that their proliferation has increased fragmentation and advanced the special interests of powerful private actors, such as philanthropic foundations and corporations, thereby undermining democratic governance and challenging the authority of organizations like the UN. The increased agenda-setting power of private actors has also shifted priorities away from addressing complex health issues rooted in political and socioeconomic inequities, toward quick fixes and market-based technological solutions. (Lie 2019: 278)

Leaders in the food industry speak of their interest in helping to solve the hunger problem, but it centers on ways to increase food production, not on ways to alleviate poverty. They ignore the fact that many farm laborers, small farmers and other workers in the food system's factories and restaurants are hungry.

The focus on primary production of food from farming and fishing ignores the huge role of food processing. Only a fraction of the money spent on food goes to farms and even less to farm workers. The FAO publishes little data and few reports on food factories. The NOVA project, based at the University of Sao Paulo in Brazil, is drawing attention to the economic and health impacts of ultra-processed foods (Monteiro et al. 2016; Monteiro et al. 2018).

\section{SUSTAINABILITY}

Back in 2010 I said:

The sustainability question is about how it will be possible to feed a much larger global population over the long term. Hunger is about the fact that more than one billion people do not get enough to eat even now, when the world has an abundant food supply. The current hunger problem is not there because the world doesn't produce enough food, or because it is produced in ways that are not sustainable. There is plenty of food. The problem is that more than a billion people are so poor 
that they cannot afford the food that is out there. The food is available, but not accessible to them. (Kent 2010b)

Many people interested in the hunger issue have been distracted by the sustainability issue. The shift of attention toward sustainability is illustrated by the One Planet Network's Sustainable Food Systems Programme (One Planet 2018a). In a discussion of their draft document on the topic (One Planet 2018b) I asked:

Why discuss sustainability as if it was the primary goal, the apex, the goal to which other objectives should be subordinated? And why focus on "key approaches, concepts and terms?” when the real underlying question is, how should food systems be designed and improved? The core objective should be the improvement of people's lives, especially poor people. Concerns about sustainability can be set aside while more serious work is done on designing the food system that is required to address the global hunger problem with serious diagnoses, commitments, and plans of action.

Surely much of the explanation for hunger's breadth and persistence is related to the dominant economic system. By its nature, it produces inequality (Kent 2000). Much of the apparent production of wealth is really about the steady transmission of the fruits of people's labor upward through the socio-economic hierarchy. As we can see from the United Nations system's annual reports on food security in world and the flow of documents from the UN's Committee on World Food Security, the system turns a blind eye to the political economy of hunger. That is not likely to be fixed if we are not willing to look at it. (Kent 2018a)

Later I added:

I see sustainability as just one item in the list of desirable qualities in many things. When I buy a car, for example, I would like it to last a long time, but that is just one consideration among many. Sustainability is important in food systems, especially those that function well. However, I don't see how it is a precondition for global food security.

The concern raised here is that shifting the focus to sustainability seems to be displacing attention to the need to make serious efforts to end hunger in the world. I have yet to see a serious plan to end hunger, one that can realistically be expected to succeed. I would like to see a more serious commitment to ending hunger in the world. When we design a system that works well for everyone, we can talk about how to sustain it. (Kent 2018a)

The shift of focus to sustainability is evident in the Ceres2030 initiative, described as a search for "Sustainable Solutions to End Hunger." They say: 
Ceres2030 will critically evaluate the agricultural interventions - the benefits, the costs, the trade-offs - that can transform the lives and incomes of the world's poorest farmers in ways that preserve the environment. (Ceres2030 2019)

What does that mean in practical terms? Who will do this critical evaluation, based on what criteria? What will be done with the findings? How will this work differ from agriculturepromotion activities that have been underway for decades? And most importantly, what reason is there to believe that this approach would make a substantial contribution to ending hunger? How would it mesh with other initiatives that are undertaken under the Ceres2030 banner and elsewhere?

The Ceres2030 brochure titled "Help us to build a global road map to end hunger" begins by saying, “Agriculture is a powerful tool to end poverty. Still, in 2016, over 815 million people went to bed hungry every night.” How are those two thoughts connected? In what way is agriculture a powerful tool to end poverty?

Many people working on farms are trapped there for lack of alternative ways to make a decent living. Whether as smallholders or laborers, their farm work provides them with nothing more than bare life, with scant hope for a better future (Edkins 2000). The best remedy might be to get them out of agriculture and into something that provides them and their children with better opportunities. Agriculture as presently organized is highly exploitative, endlessly recreating poverty. The dominant food system is itself a major cause of hunger in the world.

The brochure goes on to acknowledge that agriculture is responsible for a quarter of global greenhouse gas emissions and other environmental harms. They then link up with the Sustainable Development Goals:

Our work focuses on interventions that can improve smallholder livelihoods through increased income or productivity while minimizing environmental harm-the goals of SDG 2.3. and 2.4.

Improving smallholder livelihoods, perhaps by getting them into other means of earning a living, is important, but where is the attention to the many hungry people who are not smallholders, such as the urban poor? How much improvement are they aiming for, by when? How will the increase in their incomes compare with those enjoyed by those who are already better off? How much of the increases in their incomes will be siphoned away by their suppliers and by inflation?

The global food system is incredibly inefficient, especially if it is assessed in terms of its production of public health rather than private wealth (Keller 2019). If the hunger problem is to be solved, the entire global food system and the economic system in which it is embedded will have to be redesigned.

Where is Ceres2030's discussion of that challenge? If the authors believe that is utopian and impossible, they should be honest and say so. To claim that a project is about ending hunger while not actually believing in that possibility is misleading. If the project is only about reducing hunger in a specific place, say that. 
The Barilla Center for Food \& Nutrition, working together with The Economist Intelligence Unit, developed a Food Sustainability Index to identify best practices for moving toward the Sustainable Development Goals. The first page of their report says the recent rise in worldwide hunger is due to factors such as conflict and climate change. The report does not discuss economic forces that have kept the hunger level high even where there was little conflict and no noticeable climate change. It says that in agriculture, the goal is to increase productivity (Barilla Center 2018). How would that lead to achievement of Sustainable Development Goal 2, zero hunger? Very often, increases in farm productivity leads to increased food supply for richer people and only small increases in income for the farmers.

Another example from the recent wave of food studies centered on sustainability was provided by the World Resources Institute (World Resources Institute 2018). It gives attention to the hunger problem but does not offer a plan for getting to or close to the end of hunger.

The heavy emphasis on sustainability may be partly due to the fact that it can benefit industrial agriculture and the industries that support it (Latham 2018). The orientation is based on the idea of a trickle-down benefit. Supposedly, if a lot is done to benefit agriculture directly, that will result in benefits for at least some of the poor.

Before it was acquired by Bayer in 2018, Monsanto presented itself as helping to end hunger in the world. Bayer continues that practice, as demonstrated by its website at https://www.cropscience.bayer.com/en/stories/2016/nutrition-and-food-security-food-trends-andglobal-hunger, where they say "there are still regions where there simply isn't enough food to go around.” They don't take notice of the fact that many places with needy people use their land, water, and other resources to produce food for less needy people elsewhere. For example, India has been among the leading exporters of rice, wheat, and beef (actually buffalo) while at the same time much of its population is seriously malnourished. Brazil, Mexico and other countries have many poor people while exporting huge quantities of food. In the U.S. many states produce food for other states and other countries while much of their local population remains poor and malnourished.

For a time, concerns about sustainability centered on the issue of increasing demand resulting from population growth. However, several agencies now say that population growth is likely to be much slower and less problematic than expected (Ciluffo and Ruiz 2019; Loeffelholz 2019; Pinsker 2019; The Economist 2019; Piper 2019). Why worry so much about possible population growth in the distant future when we do so little to prevent hunger in this current world of abundance?

The attention of environmentalists has now shifted to the threats linked to climate change. Unquestionably, climate change threatens the world's food system (Flavelle 2019; Hickel 2019; IPCC 2019; Little 2019a; Little 2019b; McKie 2019). We should be cautious if concern about sustainability draws attention away from the hunger problem. It is already very real for hundreds of millions of people. 
No matter how population growth or climate change impact the global food system, there is little reason to expect the benefits of high-technology food production to trickle-down to those who are hungry. Hunger does not exist because there is not enough food in the world. There is plenty of food, as anyone can see by visiting a few supermarkets, in poor countries as well as rich countries. It is not difficult to produce food. However, it is difficult to get those who control the productive resources to produce food for people with little money. If the food industry is going to help end hunger in the world, it must find ways to help poor people provide for themselves. They could make a good start by ensuring that everyone who works in the industry gets a decent wage.

Eric Holt-Giménez, until recently the Executive Director of the Institute for Food and Development Policy (Food First), recognizes that it is entirely possible to increase food production for the world's growing population, but if nothing is done to change the fundamentals of the food system, it will still fail to end hunger (Holt-Giménez et al. 2012; Holt- Giménez 2018). Similarly, Timothy Wise makes it clear that the world already has all the means needed for feeding everyone, but does not focus on that (Wise 2019).

Some analysts are so deeply committed to sustainability in relation to climate and material resources, they overlook the ways in which the current global food system sustains hunger. Pursuing sustainability is important, but so is ending hunger.

\section{THE FOUNDATIONS OF HUNGER}

In the U.S. the food industry has allied with anti-hunger workers by providing resources for food charities, an arrangement that helps to ensure their silence on the fundamental causes of hunger (Fisher 2019). There is little discussion of the root causes of hunger in the world. Many people make overly simple assumptions that it is due to a worldwide shortage of food or due to rapid population growth. Many environmentalists identify trends or disruptions that could lead to hunger in the future, but do not discuss or explain the widespread hunger until now.

In my view there are three underlying reasons for the persistence of hunger in the world:

- Disjunction. Hunger and poverty persist largely because the people who have the power to solve the problems are not the ones who have the problems.

- Compassion. On the whole, the people who have the power do not have much compassion for the powerless and those who are suffering.

- Material interests. The powerful serve mainly the powerful, not the powerless, because the powerless cannot do much for the benefit of the powerful. In many cases the powerful exploit the powerless. (Kent 2016, 23)

The world already produces more than enough food for everyone but doesn't deliver it to everyone (Holt-Giménez et al. 2012). Much more basic nutritious food could be produced by using existing resources for that purpose, rather than for, say, flowers, and tobacco. 
Structurally, the global food system and many national food systems are based on having the poor feed the rich, though few analysts say that out loud (Kent 1982). The process is more bubble-up than trickle-down. The pattern is evident when we compare the income levels of small-scale farmers, farm laborers, waiters, food factory workers, and grocery clerks with the income levels of their customers and employers. Some people work in degrading slave-like conditions (Ferdman 20i6; Robb 2016; Schlosser 2019). The food system is a major part of the global economic system in which there is a large and widening gap between rich and poor (Luhby 2019; Matthews 2019; Roser 2016).

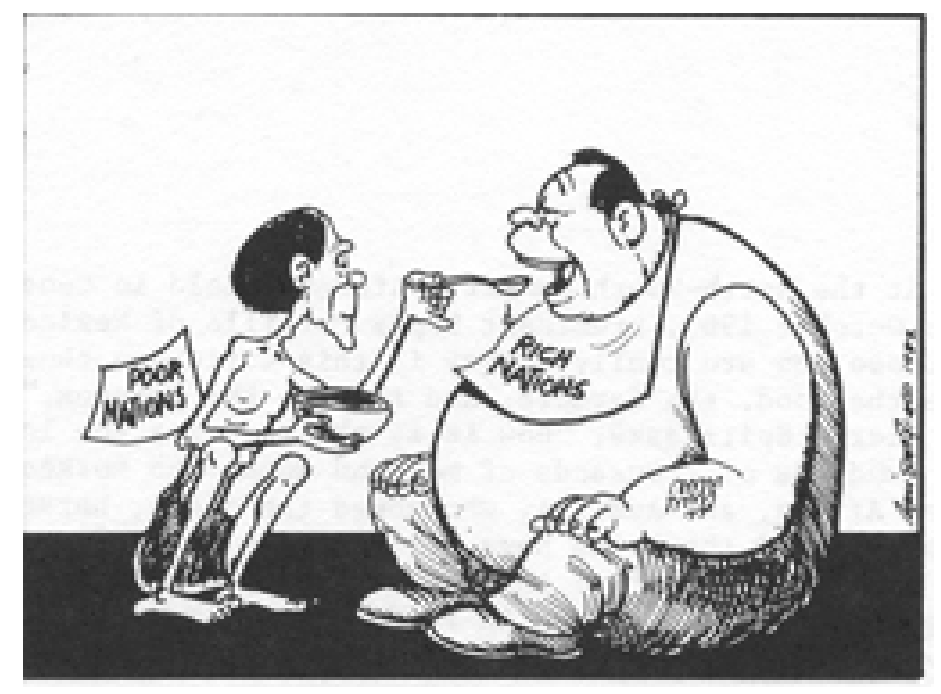

Only in that sort of world is it possible for one fish to sell for more than three million dollars (Denyer and Kashiwagi 2019). The people who caught that fish were not likely to get a taste of it. The global fish trade demonstrates the poor-feed-the-rich pattern very clearly (Kent 1997; Kent 2003; OHCHR 2019).

Some people might believe that the hunger problem can be solved through the development of genetically modified food or other technology, but that would not help if the basic structure of the food system remains the same. That technological approach brings to mind some very peculiar approaches to dealing with the hunger problem. David Denkenberger and Joshua Pearce argue it would be possible to feed everyone even after a nuclear winter or after an asteroid blocked the sun for years (Denkenberger and Pearce 2014; Wiblin and Harris 2018). If it would be so easy to feed everyone after such catastrophes, why don't we do that now, before the catastrophes?

There is little reason to believe technological innovations would end hunger in the world. People who have money bid higher for the services of farmers than people who only have needs. International trade, in particular, is all about searching the world for the highest bidder. In that system, some of us can have strawberries and sashimi all year long, while needy people cannot access adequate quantities of inexpensive staple foods.

Something should have been learned from the dashed hopes for ending world hunger with golden rice (Dawe and Unnevehr 2007; GRAIN, MASIPAG, and Stop Golden Rice Network 2018). 
Some people hope for ending hunger through technological inventions such as genetic modification and high technology industrial-style agriculture (Little 2019b), but little thought is given to the need for social inventions.

An essay on climate change concluded:

There may come a time, sooner than any of us likes to think, when the systems of industrial agriculture and global trade break down and homeless people outnumber people with homes. At that point, traditional local farming and strong communities will no longer just be liberal buzzwords. Kindness to neighbors and respect for the land—nurturing healthy soil, wisely managing water, caring for pollinators - will be essential in a crisis and in whatever society survives it. A project like the Homeless Garden offers me the hope that the future, while undoubtedly worse than the present, might also, in some ways, be better. Most of all, though, it gives me hope for today. (Franzen 2019)

\section{FINDING HOPE IN LOCAL CARING COMMUNITIES}

There is little basis for hoping that kindness to neighbors and to the environment will emerge more strongly after catastrophic climate change. Caring doesn't just happen when and where it is needed.

There is not enough caring at the global level. It is more likely to emerge at the community level. There are many communities in which people care about one another, so no one goes hungry, even if they have little money. Everyone who is hungry is poor, but not everyone who is poor is hungry. Maybe the most plausible way to end hunger in the world, and also save the environment, is to improve the ways in which people live together in local communities (Kent 2016; 2018b; 2019; O’Brien and Nisbett 2019). There is no reason to wait for catastrophic climate change before doing that. Indeed, transforming how we live now might be the best way to prevent that catastrophe.

Some analysts are beginning to realize that the sustainability and hunger issues should be addressed together (Bryce 2019; Hasegawa et al. 2019). That has not worked well at the global level. Perhaps it could be made to work at the community level. There should be way to facilitate serious planning for and by local communities to end their hunger and protect their environments at the same time.

\section{REFERENCES}

Barclay, Eliza. 2019. “The Way we Eat Could Doom us as a Species. Here’s a New Diet Designed to Save Us.” Vox. January 23. https://www.vox.com/2019/1/23/18185446/climate-change-planet-based-diet-lancet-eatcommission 
Barilla Center. 2018. Fixing Food 2018: Best Practices Towards the Sustainable Development Goals. Barilla Center for Food \& Nutrition. http://foodsustainability.eiu.com/wpcontent/uploads/sites/34/2018/12/FixingFood2018-2.pdf

Branca, Francesco et al. 2019. "Transforming the Food System to Fight Non-communicable Diseases.” BMJ 28;364:1296. https://www.bmj.com/content/bmj/364/bmj.1296.full.pdf

Bryce, Emma. 2019. "The Problem with Environmental Food Policies That Are Blind to Food Inequality.” Anthropocene. September 20. http://www.anthropocenemagazine.org/2019/09/ending-hunger-doesnt-have-to-cost-theearth/

Ceres2030. 2019. Ceres2030: Sustainable Solutions to End Hunger. https://ceres2030.org/

CFS. 2019. Committee on World Food Security. Website. http://www.fao.org/cfs/en/

Chauhan, Gauri. 2019. “Hunger’s Appetite: Five Questions for Jean Drèze.” The Citizen. July 12. https://www.thecitizen.in/index.php/en/NewsDetail/index/4/17261/Hungers-AppetiteFive-Questions-for-Jean-Drze

Ciluffo, Anthony and Neil G. Ruiz. 2019. "World Population is Projected to Nearly Stop Growing by the End of the Century." Pew Research Center. June 17. https:/www.pewresearch.org/fact-tank/2019/06/17/worlds-population-is-projected-tonearly-stop-growing-by-the-end-of-the-century/?fbclid=IwAR3VLzjBTeGc5m lHrHN1z_zqU3PiHxpMptaACYVTKpYN4UoJdoy58qpuE

Dawe, David, and Laurian Unnevehr. 2007. "Crop Case Study: GMO Golden Rice in Asia with Enhanced Vitamin A Benefits for Consumers.” AgBioForum: 154-160. http://www.agbioforum.org/v10n3/v10n3a04-unnevehr.pdf

Deen, Thalif. 2019. “Will a Global Fund Help Deliver UN’s Development Agenda?” Inter Press Service News Agency. July 19. http://www.ipsnews.net/2019/07/will-global-fund-helpdeliver-uns-development-agenda/

Denkenberger, David, and Joshua M. Pearce. 2014. Feeding Everyone No Matter What: Managing Food Security After Global Catastrophe. Elsevier Academic Press. https://www.elsevier.com/books/feeding-everyone-no-matter-what/denkenberger/978-0$\underline{12-802150-7}$

Denyer, Simon, and Akiko Kashiwagi. 2019. "Bluefin Tuna Sells for Record \$3.1 Million at Tokyo Fish Market, But Scarcity Clouds Celebration.” Washington Post. January 5. https:/www.washingtonpost.com/world/2019/01/05/bluefin-tuna-sells-record-milliontokyo-fish-market-scarcity-clouds-celebration/?utm_term=.3bdb37136374 
World Nutrition 2019;10(3):3-22

EAT. 2019. Healthy Diets From Sustainable Food Systems: Food, Planet, Health. EAT. https://eatforum.org/content/uploads/2019/01/EATLancet_Commission_Summary_Report.pdf

EAT-Lancet. 2019. EAT-Lancet Commission on Food, Planet, Health. https://eatforum.org/eatlancet-commission/

Edkins, Jenny. 2000. Whose Hunger? Concepts of Famine, Practices of Aid. Minneapolis: University of Minnesota Press.

FAO. 2018. Strengthening Sector Policies for Better Food Security and Nutrition Results. Rome: Food and Agriculture Organization of the United Nations. http://www.fao.org/3/CA2797EN/ca2797en.pdf

FAO. 2019. The State of Food Security and Nutrition in the World. Rome: Food and Agriculture Organization of the United Nations. https://data.unicef.org/resources/sofi-2019/

FAO, IFAD, UNICEF, WFP and WHO. 2018. The State of Food Security and Nutrition in the World 2018: Building Climate Resilience for Food Security and Nutrition. Rome: FAO. http://www.fao.org/3/I9553EN/i9553en.pdf

Ferdman, Roberto A. 2016. “'I Had to Wear Papmers': The Cruel Reality the People Who Bring You Cheap Chicken Allegedly Endure.” Washington Post. May 11. https://www.washingtonpost.com/news/wonk/wp/2016/05/11/i-had-to-wear-pampersmany-poultry-industry-workers-allegedly-cant-even-take-bathroom-breaks/

Fisher, Andrew. 2019. Big Hunger: The Unholy Alliance Between Corporate America and AntiHunger Groups. Cambridge, Massachusetts: The MIT Press.

Flavelle, Christopher. 2019. “Climate change Threatens the World’s Food Supply, United Nations Warns.” The New York Times, August 8. https://www.nytimes.com/2019/08/08/climate/climate-change-foodsupply.html?rref=collection\%2Fsectioncollection\%2Fclimate\&action=click\&contentColl ection=climate \&region=rank\&module=package \&version=highlights \&contentPlacement $=$ 1\&pgtype=sectionfront

Franzen, Jonathan. 2019. "What If We Stopped Pretending The Climate Apocalypse is Coming. To Prepare for It, We need to Admit hat we Can’t Prevent It.” The New Yorker. https://www.newyorker.com/culture/cultural-comment/what-if-we-stopped-pretending

Geraghty, Liam. 2019. “The UN Poverty Report Shows That we Need to Fight for the Right to Food.” The Big Issue. May 30. https://www.bigissue.com/latest/the-un-poverty-reportshows-that-we-need-to-fight-for-the-right-to-food/

Global Nutrition Report. 2019. Global Nutrition Report. https://globalnutritionreport.org/ 
GRAIN, MASIPAG, and Stop Golden Rice Network. 2018. "Don’t get Fooled Again! Unmasking Two Decades of Lies About Golden Rice.” GRAIN. November 13. https://grain.org/en/article/6067-don-t-get-fooled-again-unmasking-two-decades-of-liesabout-golden-rice

Gunawardena, Lakshi De Vass. 2019. “The Road to Zero Hunger.” Inter Press Service News Agency. July 23. http://www.ipsnews.net/2019/07/road-zero-hunger/

Hasegawa, Tomoko, Petr Havlík, Stefan Frank, Amanda Palazzo, and Hugo Valin. 2019. "Tackling Food Consumption Inequality to Fight Hunger Without Pressuring the Environment.” Nature Sustainability 2(9):826-33. September. https://www.nature.com/articles/s41893-019-0371-6

Hickel, Jason. 2016. "The True Extent of Global Poverty and Hunger: Questioning the Good News Narrative of the Millennium Development Goals.” Third World Quarterly 37(5) :749-67. https://www.tandfonline.com/doi/abs/10.1080/01436597.2015.1109439?journalCode=ct $\underline{\text { wq20 }}$

---. 2019. “The Global Food Crisis is Here.” Foreign Policy. August 21. https://foreignpolicy.com/2019/08/21/the-global-food-crisis-is-here/

Holt-Giménez, Eric, Annie Shattuck, Miguel Altieri, Hans Herren, and Steve Gliefssman. 2012. "We Already Grow Enough Food for 10 Billion People ... and Still Can't End Hunger." Journal of Sustainable Agriculture. 36(6):595-598. https://www.researchgate.net/publication/241746569_We_Already_Grow_Enough_Food for_10_Billion_People_and_Still_Can\%27t_End_Hunger

Holt-Giménez, Eric. 2018. Can We Feed the World Without Destroying It? Cambridge, UK: Polity Press.

IFPRI. 2019. International Food Policy Research Institute. Website. http://www.ifpri.org/

IPCC. 2019. Climate Change and Land. The Intergovernmental Panel on Climate Change. August 8. https://www.ipcc.ch/report/srccl/

Katz, Josh, Alicia Parlaplano, and Margot Sanger-Katz. 2019. "Almost Everywhere, Fewer Children are Dying.” The New York Times. September 17. https://www.nytimes.com/interactive/2019/09/17/upshot/child-mortality.html

Keller, Sean. 2019. "Connecting the Dots: Insane Trade and Climate Chaos.” Local Futures: Economics of Happiness. May 14. https://www.localfutures.org/connecting-the-dotsinsane-trade-and-climatechaos/?link_id=3\&can_id=7cb5759f1fd25d82a320fd9ddfd9630b\&source=email-tradeand-climate-chaos-the-rise-of-5g-technology-our-return-to-ladakh-and- 
more\&email_referrer=email_553551\&email_subject=trade-and-climate-chaos-the-riseof-5g-technology-our-return-to-ladakh-and-more

Kent, George. 1982. "Food Trade: The Poor Feed the Rich," Food and Nutrition Bulletin 4(4): 25-33 http://www.unu.edu/Unupress/food/8F044e/8F044E05.htm

---. 1984. The Political Economy of Hunger: The Silent Holocaust, New York: Praeger Publishers.

---. 1997. “Fisheries, Food Security, and the Poor,” Food Policy, 22(5):393-404. http://www2.hawaii.edu/ kent/fisheriesfoodsecurity.pdf

---. 2000. "Market Fundamentalism,” Peace \& Policy, 5(1):36. http://www2.hawaii.edu/ kent/market\%20fundamentalism.pdf

---. 2003. Fish Trade, Food Security, and the Human Right to Adequate Food. Rome: Food and Agriculture Organization of the United Nations. http://www.fao.org/docrep/006/y4961e/y4961e06.htm

---. 2004. "Strategizing the End of Global Malnutrition," SCN News (28):65-67. Geneva: United Nations System Standing Committee on Nutrition, July. http://www2.hawaii.edu/ kent/STRATEGIZING.pdf

---. 2010a. “Assessing the Millennium Summit.” Huffington Post. September 22, 2010. http://www.huffingtonpost.com/george-kent/post_901_b_735376.html

---. 2010b. “Achieve Sustainability or End Hunger?” Huffington Post. August 3. http://www.huffingtonpost.com/george-kent/achieve-sustainability-or_b_669304.html

---. 2011a. “Global Plans of Action for Health.” In Elvira Beracochea, Corey Weinstein, and Dabney Evans, eds., Rights-based Approaches to Public Health. New York: Springer Publishers, pp. 103-115.

---. 2011b. Ending Hunger Worldwide. Boulder, Colorado: Paradigm Publishers.

---. 2016. Caring About Hunger. Sparsnäs, Sweden: Irene Publishing.

---. 2018a. "Why Focus on Sustainability?" Global Forum on Food Security and Nutrition. Food and Agriculture Organization of the United Nations. November 24 and December 3, 2018. http://www.fao.org/fsnforum/comment/9230 and http://www.fao.org/fsnforum/comment/9254

---. 2018b. "Nourishing Communities.” Transcend Media Service. December 17. https://www.transcend.org/tms/2018/12/nourishing-communities/

---. 2019. “Communities as Food Environments.” UNSCN News Vol 44. Rome: United Nations System Standing Committee on Nutrition. 
Kripke, Gawain. 2019. “The Fight for Zero Hunger is Heading in the Wrong Direction.” Oxfam: The Politics or Poverty. July 19. https://politicsofpoverty.oxfamamerica.org/2019/07/fight-zero-hunger-is-wrongdirection-sofireport/?utm_source=feedburner\&utm_medium=email\&utm_campaign=Feed\%3A+oxfam america\%2Fpoliticsofpoverty+\%280xfam+America\%27s+Politics+of+Poverty\%29

Latham, Jonathan. 2018. “The Gates Foundation’s Ceres2030 Plan Pushes Agenda of Agribusiness.” Independent Science News for Food and Agriculture. https://www.independentsciencenews.org/environment/the-gates-foundations-ceres2030plan-pushes-agenda-of-agribusiness/

Lie, Ann Louise. 2019. "Power in Global Nutrition Governance: A Critical Analysis of the Establishment of the Scaling Up Nutrition (SUN) Partnership.” Global Governance 25:277-303. https://brill.com/view/journals/gg/25/2/article-p277_8.xml or https://www.researchgate.net/publication/333739251_Power_in_Global_Nutrition_Gover nance

Little, Amanda. 2919a. "Climate Change Is Likely to Devastate the Global Food Supply. But There's Still Reason to Be Hopeful.” Time. August 28. https://time.com/5663621/climatechange-food-supply/?utm_source=newsletter\&utm_medium=email\&utm_campaign=thebrief\&utm_content=20190829\&xid=newsletter-brief

---. 2019b. The Fate of Food: What We'll Eat in a Bigger, Hotter, Smarter World. New York: Harmony Books, Penguin Random House.

Loeffelholz, Tracy Matsue. 2019. “Does Earth Really Have Too Many People?” Yes! September 20. https://www.yesmagazine.org/planet/climate-change-consumption-overpopulation20190920?utm_medium=email\&utm_campaign=YTW_20190920\&utm_content=YTW 20190920+CID_95a7cdc7fb06549956e753f226e0c3f7\&utm_source=CM\&utm_term=Do es\%20Earth\%20Really\%20Have\%20Too\%20Many\%20People

Luhby, Tami. 2019. “The Top 26 Billionaires Own \$1.4 Trillion-As Much as 3.8 Billion Other People. CNN Business. January 21. https://www.cnn.com/2019/01/20/business/oxfambillionaires-davos/index.html

Matthews, Dylan. 2019. “Are 26 Billionaires Worth More Than Half the Planet? The Debate, Explained.” Vox. January 22. https://www.vox.com/futureperfect/2019/1/22/18192774/oxfam-inequality-report-2019-davos-wealth

McKie, Robin. 2019. "We Must Transform Food Produciton to Save the World, Says Leaked Report.” The Guardian. August 4. https://www.theguardian.com/environment/2019/aug/03/ipcc-land-use-food-productionkey-to-climate-crisis-leaked-report 
Monteiro, Carlos A. et al. 2016. NOVA: The Star Shines Bright.” World Nutrition. JanuaryMarch. 7(1-3). https://worldnutritionjournal.org/index.php/wn/article/view/5/4

---. 2018. "The UN Decade of Nutrition, the NOVA Food Classification and the Trouble with Ultra-Processing.” Public Health Nutrition. January. 21(1):5-17. https://www.cambridge.org/core/journals/public-health-nutrition/article/un-decade-ofnutrition-the-nova-food-classification-and-the-trouble-withultraprocessing/2A9776922A28F8F757BDA32C3266AC2A

Nestle, Marion. 2019a. US Votes No on Action on Global Nutrition. Food Politics. January 2. https://www.foodpolitics.com/2019/01/us-votes-no-on-action-on-global-nutrition/

---. 2019b. "Last Chance to Comment on 2030 Food and Nutrition Objectives.” Food Politics. https://www.foodpolitics.com/2019/01/last-chance-to-comment-on-2030-food-andnutrition-objectives/

O’Brien, Emily, and Nicholas Nisbett. 2019. "Building a Sustainable Food City: A Collective Approach.” IDS Bulletin. July. 50 (2):111-120. https://opendocs.ids.ac.uk/opendocs/bitstream/handle/123456789/14605/IDSB50.2_10.19 0881968-2019.121.pdf?sequence=1\&isAllowed=y

---. 2019c. “Food Industry Efforts to Fight Hunger?” Food Politics. June 6. https://www.foodpolitics.com/2019/06/food-industry-efforts-to-fight-hunger/

OHCHR. 2019. Cheap Seafood Endangers Fish Workers Right to Food - UN Expert. Geneva: Office of the High Commissioner for Human Rights. February 28. https://www.ohchr.org/EN/NewsEvents/Pages/DisplayNews.aspx?NewsID=24228\&Lang $\underline{\mathrm{ID}}=\mathrm{E}$

One Planet. 2018a. Sustainable Food Systems Programme. http://www.oneplanetnetwork.org/sustainable-food-system

---. 2018b. Towards a Common Understanding of Sustainable Food Systems: Key Approaches, Concepts and Terms. Draft V1.0. http://www.fao.org/fsnforum/sites/default/files/files/155_understanding-sustainable-foodsystems/Draft_SFS_Glossary_v22NOV2018.pdf

Pearson, Anya. 2019. “The Planetary Health Diet Isn’t Much use to People Living in Food Poverty.” Global Policy. January 22. https://www.globalpolicyjournal.com/blog/22/01/2019/planetary-health-diet-isnt-muchuse-people-living-food-poverty

Pinsker, Joe.2019. “What Happens When the World’s Population Stops Growing?” The Atlantic. July 31. https://www.theatlantic.com/family/archive/2019/07/world-population-stopgrowing/595165/ 
Piper, Kelsey. 2019. 'We’ve Worried About Overpopulation for Centuries. And We’ve Always Been Wrong.” Vox. August 20. https://www.vox.com/futureperfect/2019/8/20/20802413/overpopulation-demographic-transition-populationexplained

Pogge, Thomas. 2004. “The First United Nations Millennium Development Goal: A Cause for Celebration?” Journal of Human Development, 5(3):377-97. https://www.tandfonline.com/doi/abs/10.1080/1464988042000277251

---. 2016. “The Hunger Games.” Food Ethics. 1:9-27. http://link.springer.com/article/10.1007/s41055-016-0006-9

Robb, Simon. 2016. Chicken Factory Workers 'Force to Wear Nappies on Assembly Line." Metro. May 12. https://metro.co.uk/2016/05/12/chicken-factory-workers-forced-to-wearnappies-on-assembly-line-5877934/

Roser, Max. 2016. “Global Economic Inequality.” Our World in Data. https://ourworldindata.org/global-economic-inequality

Roser, Max and Hannah Ritchie. 2019. Hunger and Undernourishment. Our World in Data. https://ourworldindata.org/hunger-and-undernourishment

Schlosser, Eric. 2019. "Why it’s Immigrants Who Pack Your Meat.” The Atlantic. August 16. https://www.theatlantic.com/ideas/archive/2019/08/trumps-invasion-was-a-corporaterecruitment-drive/596230/?utm_source=FERN+Newsletter+Service\&utm_camp

Steele, Benjamin David. 2019. “Dietary Dictocrats of E AT-Lancet.” Marmalade. https://benjamindavidsteele.wordpress.com/2019/01/21/dietary-dictocrats-of-eatlancet/amp/?_twitter_impression=true

The Economist. 2019. “A School for Small Families: Thanks to Education, Global Fertility Could Fall Faster Than Expected.” The Economist. February 2. https://www.economist.com/international/2019/02/02/thanks-to-education-globalfertility-could-fall-faster-than-expected

The Hunger Project. 1985. Ending Hunger: An Idea Who Time Has Come. New York: Praeger.

The Lancet. 2019a. The Global Syndemic of Obesity, Undernutrition and Climate Change: The Lancet Commission Report:The Global Syndemic-A Policy Brief. https://www.foodpolitics.com/wp-content/uploads/ObesityCommission_PolicyBrief_Lancet_19.pdf

---. 2019b. The Lancet. The Global Syndemic of Obesity, Undernutrition, and Climate Change: The Lancet Commission Report. https://www.thelancet.com/journals/lancet/article/PIIS0140-6736(18)32822-8/fulltext 
---. 2019c. “Transforming Food Systems for Better Health.” The Lancet. February 23. 393 (10173. 3031. https://www.thelancet.com/action/showPdf?pii=S01406736\%2818\%2933249-5

UNSCN. 2019. "Bringing Nutrition Beyond Rome.” United Nations System Standing Committee on Nutrition. https://www.unscn.org/en/news-events/story-detail?id=20

UNGA. 2018. Global health and Foreign Policy: A Healthier World Through Better Nutrition. United Nations General Assembly. A/73/L.62. December 10. https://undocs.org/en/A/73/L.62

UN Millennium Project. 2005. Halving Hunger: It Can be Done. Task Force on Hunger. http://csd.columbia.edu/files/2018/04/UN-Millennium-Project-2005-Hunger-Task-Force$\underline{\text { Report.pdf }}$

USDA. 2019. Food Security in the U.S.: Overview. United States Department of Agriculture. https://www.ers.usda.gov/topics/food-nutrition-assistance/food-security-in-the-us/

WBCSD. 2019. Food, Land and Water. World Business Council for Sustainable Development. https://www.wbcsd.org/Programs/Food-Land-Water

---. 2017. 25 Leading Companies Join together to Accelerate Transformational Change in Global Food Systems. FReSH--the Food Reform for Sustainability and Health Program. https://www.solvay.com/sites/g/files/srpend221/files/201807/FReSH\%20announcement.PDF

Wiblin, Robert, and Keiran Harris. 2018. We Could Feed all 8 Billion People Through a Nuclear Winter. Dr David Denkenberger is Working to Make it Practical.” 80,000 Hours. December 27. https://80000hours.org/podcast/episodes/david-denkenberger-allfed-andfeeding-everyone-no-matter-what/

Willett, Walter et al. 2019. "Food in the Anthropocene: The EAT-Lancet Commission on Healthy Diets from Sustainable Food Systems.” The Lancet Commissions. January 16. https://mail.google.com/mail/u/1/\#inbox/WhctKJVJdnwLqqDcHKqCBdwkLnJDJtDhfQg VCZKXWZSgXDJMXbgwgqTghRmRwQpxSdhHTKG?projector=1\&messagePartId=0. $\underline{1}$

Wise, Timothy. 2019. Eating Tomorrow: Agribusiness, Family Farmers, and the Battle for the Future of Food. New York: The New Press. https://thenewpress.com/books/eatingtomorrow?mc_cid=2d3a1d2d51\&mc_eid=80bad9391f\&mc_cid=2d3a1d2d51\&mc_eid=8 Obad9391f

World Resources Institute. 2018. Creating a Sustainable Food Future: A Menu of Solutions to feed Nearly 10 Billion People by 2050. WRI. https://www.wri.org/sites/default/files/wri13_report_4c_wrr_online.pdf 